\title{
WYKORZYSTANIE NUMERYCZNYCH MODELI TERENU W BADANIACH ZMIAN ŚRODOWISKA GEOGRAFICZNEGO MIASTA MYSLOWICE
}

Zarys treści: Celem niniejszego opracowania jest wykazanie przydatności metod analizy w oprogramowaniu GIS, w szeroko pojętych badaniach nad zmianami środowiska geograficznego miasta Mysłowice. Środowisko geograficzne tworzą elementy przyrodnicze oraz antropogeniczne, przedstawiane na mapach od stuleci. Przyjęta metoda badawcza wykazała bardzo duże możliwości zastosowania oprogramowania GIS do przeanalizowania zmian zachodzących na terenie miasta Mysłowice w latach 1883-1993.W tym celu wygenerowano dwa numeryczne modele terenu (NMT), przez zwektoryzowanie izohips oraz punktów wysokościowych. Pierwszy model wygenerowano na bazie starych niemieckich map topograficznych Messtischblatt w skali 1:25000 z lat 1883-1942. Drugi model powstał z map topograficznych Polski w skali 1:10 000 z roku 1993. Wszystkie wyżej wymienione mapy zostały skalibrowane (zarejestrowane) do wspólnego układu współrzędnych Polska 1992. Wygenerowanie różnowiekowych NMT dało także możliwość śledzenia zmiany morfologii na wybranych liniach przekrojów. Mysłowice są miastem Górnośląskiego Zagłębia Węglowego, w którym aktywność eksploatacyjna trwa już od ponad dwustu lat. Jednak ze względu na problem dostępności map, praca pokazuje jedynie 110-letnie skutki eksploatacji. Przydatność metody potwierdziła się w precyzyjnym określaniu rejonów miasta najmocniej dotkniętych skutkami eksploatacji górniczej, co zweryfikowano w terenie. Skutki podziemnej działalności górniczej są zatarte przez ślady eksploatacji powierzchniowej w kilku dużych kamieniołomach, jednak przy dokładnej analizie można je od siebie odróżnić. Dzięki oprogramowaniu GIS i precyzyjnej kalibracji starych map możliwym stanie się prześledzenie zmian zachodzących w elementach środowiska geograficznego, takich jak rzeki, zbiorniki wodne, drogi, rozwój zabudowy, zalesienie. Ponadto oprogramowanie umożliwi dokładną lokalizację niektórych nieistniejących już elementów środowiska, w tym starych wyrobisk surowców piasku, gliny i wapieni oraz śladów po dawnych hutach żelaza.

Słowa kluczowe: GIS, kartografia historyczna, numeryczny model terenu, deformacje górnicze. 


\section{Wprowadzenie}

Mysłowice są położone w północnej części Górnośląskiego Zagłębia Węglowego (GZW), będącego największym polskim obszarem górniczym. Udokumentowana eksploatacja węgla kamiennego na jego terenie trwa w nieprzerwany sposób od połowy XVIII wieku (Jaros 1965). Oprócz węgla kamiennego eksploatowano także inne surowce, takie jak rudy żelaza, cynk, ołów, srebro, wapień, piasek i glinę. Wielowiekowy okres górnictwa na terenie GZW spowodował usunięcie z podłoża i powierzchni łącznie ponad 15-17 mld ton surowców mineralnych i skał płonnych (Dulias 2013). Długi okres nieprzerwanego oddziaływania człowieka na środowisko spowodował znaczne i różnorodne zmiany rzeźby terenu, które są tematem opracowań dotyczących całego regionu (Dulias 2013), poszczególnych miast (Wojciechowski 2007) lub wybranych regionów (Mazurek 2014).

W Mysłowicach eksploatacja węgla kamiennego trwa od około 250 lat. Działalność wydobywcza w latach 1883-1993 powodowała nieustannie zmiany rzeźby poprzez:

1) eksploatację powierzchniową surowców, takich jak wapień, rudy darniowe, piasek, a także początkowo węgiel kamienny,

2) płytką eksploatację podziemną węgla (prowadzoną na głębokości od 0 do maksymalnie $300 \mathrm{~m}$ ), trwającą od połowy XVIII wieku do II wojny światowej (głównie metodą z zawałem stropu, z wyjątkiem kopalni Mysłowice stosującej podsadzkę płynną od 1902 roku),

3 ) intensywną powojenną eksploatację węgla, doprowadzoną obecnie do głębokości poniżej $800 \mathrm{~m}$, ze stosowaniem metody z zawałem stropu oraz podsadzki płynnej.

Biorąc pod uwagę historię kopalnictwa, głębokość oraz zasięg eksploatacji wydzielono dla Mysłowic trzy strefy, różniące się stopniem zaistniałych zmian morfologicznych.

W celu określenia stopnia zmian rzeźby terenu jakie nastąpiły w latach 18831993 stworzono i porównano dwa numeryczne modele terenu (NMT): pierwszy, oparty o materiały archiwalne, przedstawiający historyczny stan rzeźby terenu oraz drugi, przedstawiający współczesny stan powierzchni terenu; następnie poddano je analizie porównawczej. Oprogramowanie GIS zastosowane w opracowaniu pozwoliło na wizualizację zmian rzeźby terenu za pomocą wygenerowanych map i profili morfologicznych.

\section{Charakterystyka obszaru badań}

Według regionalizacji fizycznogeograficznej Polski (Kondracki 2002) Mysłowice leżą w południowej części Wyżyny Śląskiej, w obrębie Płaskowyżu Katowickiego (ryc. 1). Miasto zajmuje obszar o powierzchni $65,62 \mathrm{~km}^{2}$. Jego położenie na obszarze Górnośląskiego Zagłębia Węglowego, będącego jednym z najbardziej 
zasobnych w Europie złóż węgla kamiennego, zdeterminowało kierunek gospodarczego rozwoju. Historia eksploatacji węgla kamiennego na obszarze Mysłowic sięga XVIII wieku. Od 1770 roku wydobywano węgiel z kopalni Wesollaer Grube w południowej części miasta, a w 1797 roku uzyskała nadanie kopalnia Karol, leżąca w części centralnej (Jaros 1972). Od tego momentu liczba kopalń oraz sumaryczna powierzchnia pól górniczych systematycznie rosły, zajmując w 1902 roku 68\% powierzchni Mysłowic (ryc. 2). Liczbę kopalń istniejących w latach 1802-1902 można oszacować na ponad 60 (Jaros 1972).

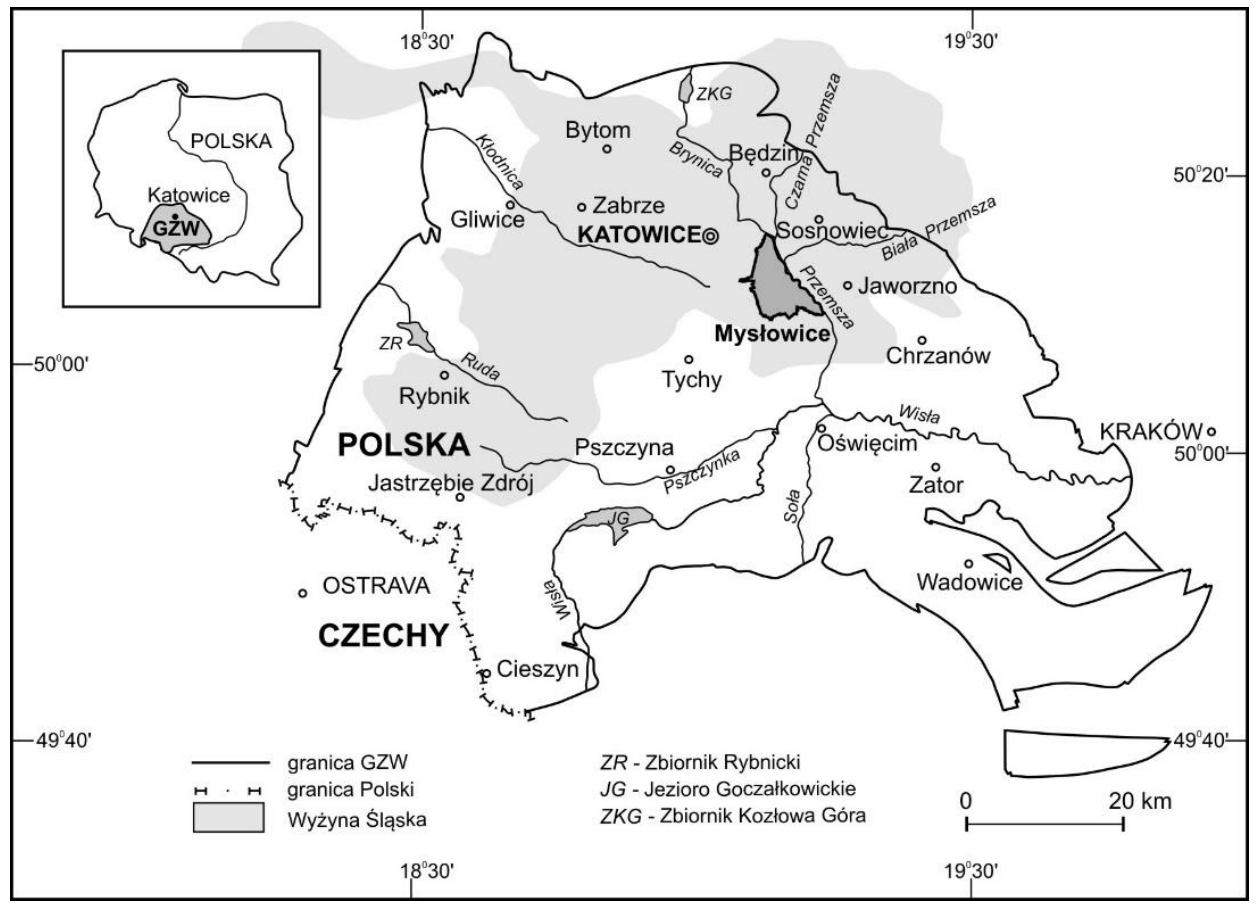

Ryc. 1. Położenie Mysłowic na tle Górnośląskiego Zagłębia Węglowego Źródło: J. Jureczka (2005) zmodyfikowany

Później, w wyniku centralizacji kapitału, liczba kopalń mysłowickich zmniejszyła się do czterech w roku 1930. Były to kopalnie: Mysłowice, Książę, Nowa Przemsza i Karol (ryc. 2). Dwie ostatnie wkrótce potem zamknięto (Nowa Przemsza została unieruchomiona w 1932 roku, Karol w 1931 roku).

Ze wszystkich kopalń mysłowickich do drugiej wojny światowej jedynie kopalnia Mysłowice przekroczyła głębokość eksploatacji 300 m (Długoborski 1977; Jaros 1990). Jednak ponad stuletnia płytka eksploatacja górnicza na pozostałych obszarach wydobywczych miasta spowodowała widoczne zmiany powierzchni terenu. Po drugiej wojnie światowej eksploatacja węgla kamiennego uległa intensyfikacji. Jeszcze podczas wojny, w 1944 roku, rozpoczęto budowę 
kopalni Ziemowit (Günther) (Jaros 1972). W czasach powojennych węgiel wydobywano z coraz głębszych pokładów oraz rozszerzano pola eksploatacji. Kopalnia Mysłowice dotarła ostatecznie do poziomu wydobywczego $690 \mathrm{~m}$ (Jaros, Sulik 1990; Sulik 1997). W 2007 roku połączono ją z kopalnią Wesoła (wcześniej kopalnia Książę) i obecnie KWK Mysłowice-Wesoła prowadzi prace na głębokości ponad $800 \mathrm{~m}$, a Ziemowit wydobywa węgiel z ponad $600 \mathrm{~m}$.

W 1993 roku proces wydobycia węgla w rejonie Mysłowic trwał już od ponad 220 lat. Tym samym można uznać, że eksploatacja węgla kamiennego stała się główną przyczyną zmian rzeźby terenu na obszarze miasta.

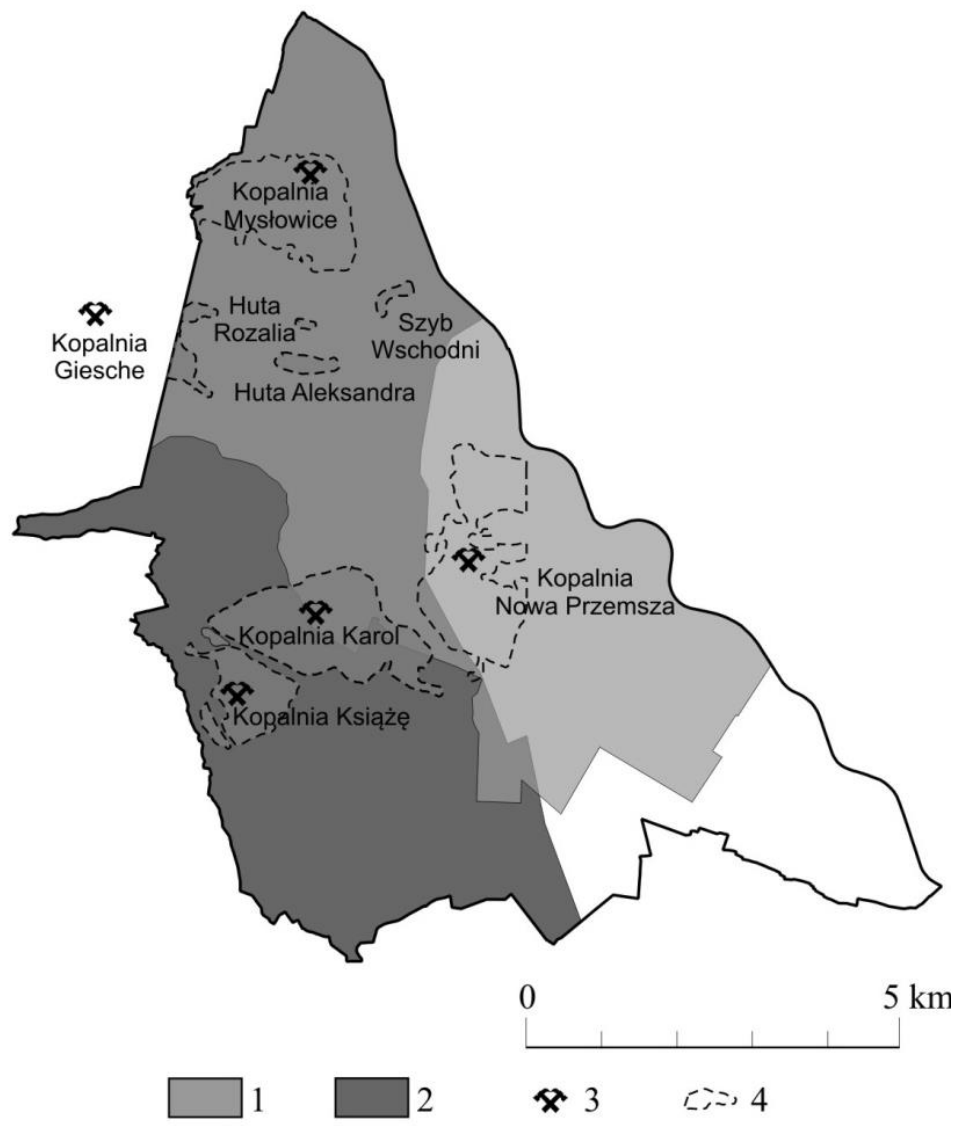

Ryc. 2. Położenie kopalń i pól górniczych w Mysłowicach

Objaśnienia: 1 - obszary pól górniczych w 1902 roku, 2 - obszary pól górniczych w 1993 roku, 3 - lokalizacja kopalń w 1930 roku, 4 - „miejsca podkopane” według mapy topograficznej z 1933 roku

Źródło: opracowanie własne 


\section{Wykorzystane materiały i metodyka badań}

W celu określenia stopnia deformacji powierzchni terenu, będącej skutkiem ponad dwustuletniej działalności górniczej w Mysłowicach, przeprowadzono analizę porównawczą danych topograficznych, zawartych na mapach z 1883 i 1993 roku. Na potrzeby opracowania wykorzystano następujące materiały kartograficzne:

- pruskie mapy górnośląskich kopalń i pokładów węgla - arkusze Mysłowice i Imielin z 1860 roku oraz tzw. Flötzkarte z 1902 roku,

- niemieckie mapy topograficzne z topografią na rok $1883 \mathrm{w}$ skali 1:25 000, tzw. Messtischblatty z 1883 roku (arkusze: 5781 Birkental i 5881 Imielin),

- niemieckie mapy topograficzne z topografią na rok 1883 w skali 1:25 000, tzw. Messtischblatty z 1942 roku (arkusze: 5780 Kattowitz i 5880 Lendzin),

- polskie mapy topograficzne z 1933 roku w skali 1:25 000, wydane przez Wojskowy Instytut Geograficzny (arkusze: Katowice, Mysłowice, Jaworzno, Bieruń Stary, Imielin),

- polskie mapy topograficzne z 1993 roku w skali 1:10 000 (arkusze: Katowice Szopienice, Sosnowiec, Katowice Giszowiec, Mysłowice Wesoła, Mysłowice, Mysłowice Brzezinka, Mysłowice Dziećkowice, Mysłowice Imielin, Lędziny i Jaworzno Jeleń),

- dane wektorowe dotyczące aktualnych i archiwalnych pól górniczych (Centralna Baza Danych Geologicznych Państwowego Instytutu Geologicznego).

Rastrowe materiały kartograficzne zostały w miarę potrzeb poddane wstępnej obróbce, polegającej na przycięciu i wyprostowaniu w programie graficznym GIMP 2.0. Mapy zarejestrowano w oparciu o znajdujące się na nich współrzędne geograficzne zapisane w układach Ferro i Greenwich. Dzięki możliwości dokonywania transformacji układów współrzędnych w programie Global Mapper, przetwarzane mapy udało się sprowadzić do jednego wspólnego układu współrzędnych prostokątnych Polska 1992/19.

Mapy nie posiadające układów geograficznych zostały zarejestrowane ręcznie (30 punktów na arkusz). Mapy górnicze Górnego Śląska z zaboru pruskiego Floztkarte des Oberschlesischen Steinkohlenbeckens w skali 1:10 000, wydawnictwo Leopolda Kraatza z 1902 roku, posiadające lokalny układ współrzędnych „Sucha Góra”, zostały zarejestrowane na podstawie skorowidzu Sucha Góra dla Górnego Śląska, opracowywanego przez mgr M. Szubę, we współpracy z mgr inż. W. Serewisiem z Wojewódzkiego Ośrodka Dokumentacji Geodezyjnej i Kartograficznej.

Dane topograficzne i wybrane elementy rzeźby terenu zwektoryzowano ręcznie w programie Global Mapper, co pozwoliło na utworzenie dwóch modeli wysokościowych. Pierwszy skonstruowany został na podstawie materiałów archiwalnych, a więc przedstawia historyczny stan rzeźby terenu. Drugi model przedstawia powierzchnię terenu $\mathrm{z}$ lat 90 . XX wieku, jako że materiałem podstawowym w jego tworzeniu były mapy topograficzne wydane w 1993 roku. Po zdigitalizo- 
waniu materiałów kartograficznych modele zostały wygenerowane za pomocą opcji przetwarzania „Create Elevation Grid from 3D vector data...”, która generuje triangulacyjne modele wysokościowe. Następnie używając opcji „Combine/ Compare Terrain Layers...” można było kontynuować pracę na modelach.

Przy założeniu, że obszar miasta ulegał obniżaniu wskutek eksploatacji górniczej, odjęto powierzchnie wysokościowe archiwalnego modelu wysokościowego od współczesnego. W ten sposób uzyskano mapę różnic wartości względnych, jakie powstały w okresie od 1883 do 1993 roku (ryc. 4). Jednakże pierwotny efekt odejmowania dał zarówno wyniki ujemne, potwierdzające tezę o obniżaniu się powierzchni terenu na skutek działalności wydobywczej, jak i wyniki dodatnie świadczące o podniesieniu terenu, co było mało prawdopodobne.

Dzięki uprzejmości dr D. Dukaczewskiego z Instytutu Geodezji i Kartografii w Warszawie autorzy uzyskali informację, że „pod koniec XIX wieku niwelacja w miarę oddalania się od punktu odniesienia stawała się coraz mniej precyzyjna”. $\mathrm{Na}$ tej podstawie oraz po konsultacji wstępnych wyników analizy z ekspertami Działu Mierniczo-Geologicznego kopalni Mysłowice-Wesoła, uwzględniono $3 \mathrm{~m}$ poprawki do wysokości bezwzględnych otrzymanych po wektoryzacji map z 1883 roku. Wyniki otrzymane po wprowadzeniu poprawionego modelu dały zadowalające efekty.

Ostateczna forma graficzna materiałów wygenerowanych dla potrzeb opracowania została przygotowana za pomocą programów Global Mapper i Corel Draw.

\section{Analiza wyników}

Numeryczny model terenu uzyskany z wektoryzacji map topograficznych z 1883 roku wykazał deniwelacje od 338 do 240 m n.p.m. Model wygenerowany z map z 1993 roku wykazuje deniwelacje rzędu 333,9-236,25 m n.p.m. Na tej podstawie można stwierdzić, że obszar Mysłowic obniżył się średnio o cztery metry w okresie 1883-1993.

Nie zmieniło się położenie obszarów miasta o maksymalnym i minimalnym wyniesieniu. Obszary najwyżej położone leżą w środkowo-zachodniej części miasta. Tereny najniżej położone zajmują południowo-wschodnią część Mysłowic, wzdłuż doliny Przemszy (ryc. 4).

$\mathrm{Na}$ otrzymanym obrazie przedstawiającym zmiany wysokości względnych Mysłowic w latach 1883-1993 wydzielono rejony, których nie brano pod uwagę podczas analizy. Są to rejony charakteryzujące się występowaniem znaczących skutków antropogenicznych przekształceń powierzchniowych (ryc. 3). Należą do nich:

1. Dwa obszary dawnej eksploatacji piasków podsadzkowych, o bardzo ubogim rysunku poziomicowym na mapach topograficznych z 1883 roku, przekształ- 
cone później w zbiorniki wodne. Pierwszy z nich leży na północy miasta (stawy Hubertus), drugi na południowym wschodzie (osadnik elektrociepłowni Jaworzno III).

2. Obszar linii kolejowych, drogi ekspresowej S1, autostrady A4 i fragmenty niedawno modernizowanych dróg. Są to obszary przerywające ciągłość rysunku poziomicowego, w większej części przebiegające na wysokich nasypach. Uwzględnienie geodezyjnych punktów pomiarowych położonych w tych miejscach mocno zniekształca model numeryczny terenu, generując w miejscach punktów geodezyjnych położonych na nasypach wypukłe, stożkowate formy.

3. Obszary o wysokim stopniu przekształceń antropogenicznych (infrastruktura kopalniana, dworzec kolejowy).

Przeprowadzone badania wykazały, że na terenie Mysłowic w okresie 18831993 doszło do powstania deniwelacji od $-22 \mathrm{~m}$ do $13 \mathrm{~m}$ (wysokości względne). Otrzymanie wartości ujemnych w przypadku omawiania terenu osiadającego przez 110 lat jest oczywiste. Natomiast wyniki dodatnie wymagają określenia prawdopodobnych przyczyn ich powstania. Mogą to być błędy wynikające z różnic precyzji pomiarów geodezyjnych w latach 1883 i 1993, zastosowania map o różnych układach odniesienia (mapy niemieckie - Amsterdam, polskie - Kronsztad) lub błędy wynikające z generalizacji i przeskalowań niemieckich archiwalnych map topograficznych.

Inną możliwą przyczyną błędu może być nieuwzględnienie w trakcie XIX-wiecznych pomiarów geodezyjnych faktu, że punkty reperowe osiadały razem $\mathrm{z}$ całym terenem, czyli dowiązywanie się do nich w trakcie pomiarów było obarczone błędem. Mapy z 1883 roku przedstawiają efekty początkowej, bardzo płytkiej eksploatacji górniczej, która szybko się objawiła w rzeźbie powierzchni terenu (w roku 1883 jedynie kopalnia Mysłowice doszła do poziomu eksploatacji $135 \mathrm{~m}$ ). Obecność zdecydowanej większości obszarów wyniesionych przedstawionych na mapie na ryc. 3 może być uzasadniona następującymi przyczynami:

1. Obszar o największych wartościach wyniesień, rzędu $13 \mathrm{~m}$, w południowo-wschodniej części Mysłowic, na obszarze kamieniołomu wapieni i dolomitów powstałe wyniesienie wynika $\mathrm{z}$ niedokładności wrysowania poziomic wzdłuż kanału odwadniającego kamieniołom, co wyraźnie widać podczas jednoczesnego podglądu rysunku poziomicowego na mapach archiwalnych i współczesnych.

2. Obszary wyniesione nawet do około $9 \mathrm{~m}$, leżące wzdłuż wschodniej granicy, w północnej części miasta, nad Przemszą, jak również wyniesienia rzędu $7 \mathrm{~m}$ na wapiennym pagórze i dwa mniejsze rzędu 2-3 $\mathrm{m}$ w południowo-zachodniej części miasta wynikają z braku wrysowania poziomicy głównej na mapach archiwalnych. Na archiwalnych mapach w tych rejonach występują duże odległości między poziomicami, nawet powyżej $450 \mathrm{~m}$. Na tych obszarach z pewnością nie prowadzono żadnych prac, które mogły spowodować powstanie wzniesień. Jest to wyraźnie widoczne na ryc. 5 na linii A-B, gdzie profil morfologiczny wygenerowany $\mathrm{z}$ archiwalnych map niemieckich daje obraz wzgórza o zupełnie płaskim wierzchołku, niższego niż obecnie. 


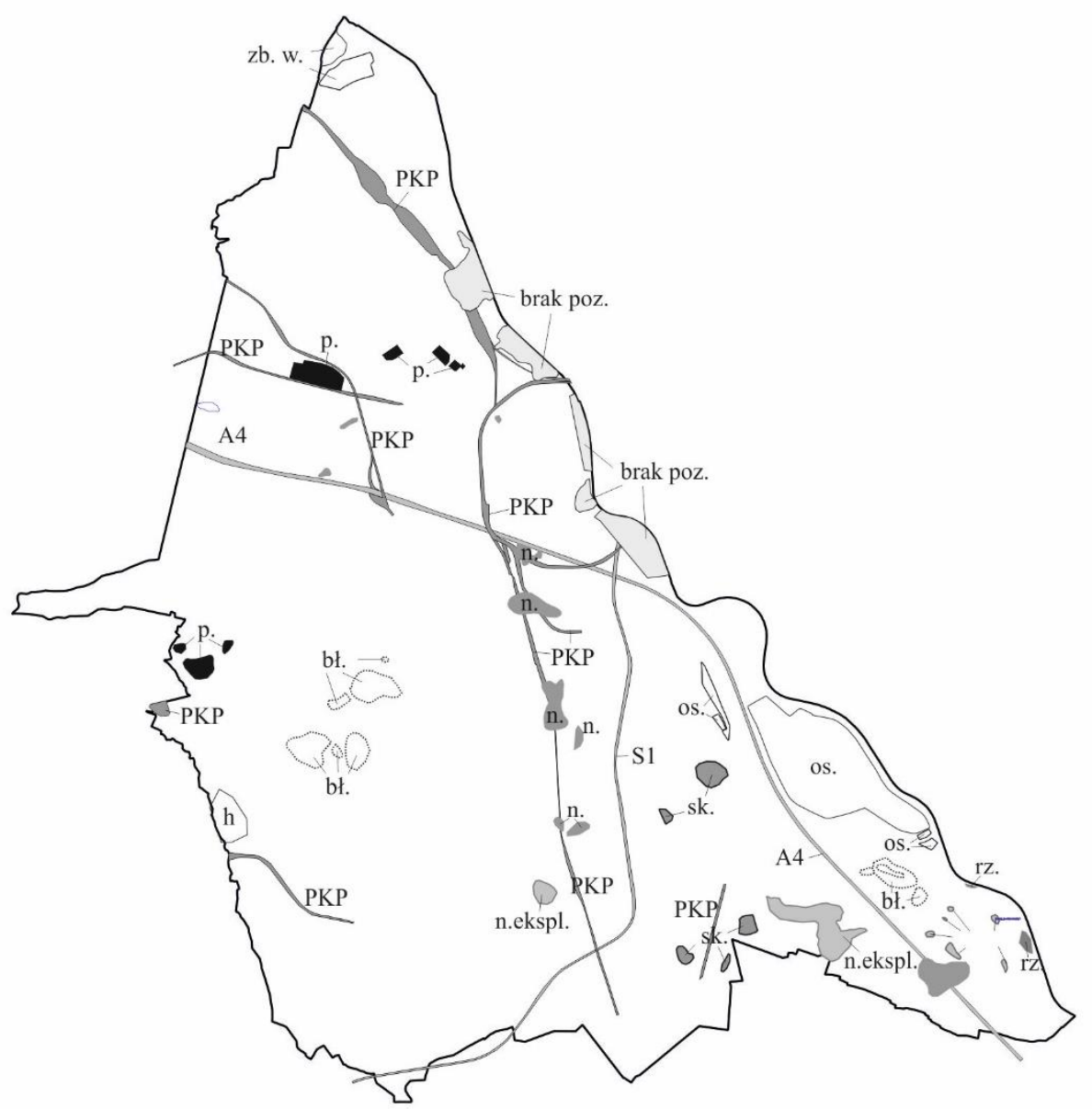

Ryc. 3. Mapa przedstawiająca obszary bez danych oraz wyniesienia

Objaśnienia: zb.w. - zbiornik wodny, os. - osadnik, PKP - kolej, A4 - autostrada, $\mathrm{S} 1$ - droga ekspresowa, $\mathrm{h}$ - hałdy, $\mathrm{n}$. - obszary związane prawdopodobnie $\mathrm{z}$ nasypami drogowymi lub kolejowymi, p. - obszary przemysłowe, bł. - wyniesienia będące prawdopodobnie wynikiem błędu w rysunku poziomicowym na mapach archiwalnych, brak poz. - obszary o małym zagęszczeniu poziomic, rz. - wyniesienia powstałe wskutek regulacji rzeki, n.ekspl. - wyniesienia będące prawdopodobnie skutkiem nasypów poeksploatacyjnych (wapiennych), sk. - wyniesienia poniżej $2 \mathrm{~m}$, wynikające $\mathrm{z}$ różnej generalizacji map

Źródło: opracowanie własne

3. Wyniesienia różnej wielkości, od 2 do $9 \mathrm{~m}$, rozrzucone na całym terenie miasta, w bezpośrednim lub bliskim sąsiedztwie linii kolejowych lub nasypów drogowych, zwłaszcza nowych dróg: autostrady A4 i drogi ekspresowej S1 oraz 
dróg lokalnych, można tłumaczyć tworzeniem nasypów pod nowe drogi lub nadsypywaniem podczas częstych $w$ tym rejonie napraw dróg.

4. Pozostałe wyniesienia, rzędu niespełna $2 \mathrm{~m}$, również rozmieszczone nieregularnie na całym obszarze miasta, są związane najprawdopodobniej z nasypami poeksploatacyjnymi (hałdy kopalniane, nieczynny kamieniołom), wyrównywaniem i nadsypywaniem terenu podczas rozbudowy miasta lub z niedokładnościami związanymi $\mathrm{z}$ niewielkimi przesunięciami rysunku poziomicowego na granicach arkuszy map.

Szereg niedokładności objawiających się w postaci rzekomo powstałych wyniesień jest następstwem błędów niedokładności rysowania lub pomiarów oraz różnicy skal między mapami archiwalnymi i współczesnymi, co jest widoczne podczas analizy profili morfologicznych przedstawionych na ryc. 5. Pomimo wymienionych możliwych błędów stosowano już archiwalne mapy niemieckie do tego typu opracowań (Wojciechowski 2007), uzyskując wiarygodne wyniki. Również w przypadku niniejszego opracowania otrzymane wyniki dotyczące rzędu wielkości osiadania zostały potwierdzone przez porównanie z informacją o osiadaniach terenu w obszarze badań uzyskanych z Katowickiego Holdingu Węglowego.

Biorąc pod uwagę aspekt historyczny kopalnictwa węgla kamiennego na terenie miasta oraz głębokość eksploatacji, na obszarze Mysłowic można wyróżnić trzy strefy, które na mapie na ryc. $4 \mathrm{c}$ przedstawione są na tle różnicy wysokości terenu obliczonej po nałożeniu NMT 1883 i 1993. Strefy te można scharakteryzować następująco:

1. Strefa I zajmująca $42,3 \mathrm{~km}^{2}$ (64\% powierzchni miasta), w której eksploatacja była prowadzona $\mathrm{w}$ sposób ciągły od początków kopalnictwa w połowie XVIII wieku do roku 1993. W tym rejonie w 1993 roku prowadziły eksploatację kopalnie: Mysłowice, Wesoła, Wieczorek, Staszic, Siemianowice, Ziemowit i Niwka-Modrzejów. Wszystkie te kopalnie powstały w XIX wieku, z wyjątkiem kopalń Wesoła i Ziemowit.

2. Strefa II o powierzchni $16,2 \mathrm{~km}^{2}$ (25\% powierzchni miasta), w której istniała wyłącznie płytka eksploatacja węgla kamiennego nie przekraczająca $300 \mathrm{~m}$ głębokości, zakończona w latach 30. ubiegłego wieku (Jaros 1965, 1969). W tym rejonie najdłużej eksploatowała węgiel kopalnia Nowa Przemsza (ryc. 2). Ponieważ literatura podaje różne lata zamknięcia tej kopalni, sięgnięto do akt Archiwum Wyższego Urzędu Górniczego. Na dokumencie „Karta tytułowa kopalni Nowa Przemsza” widnieje adnotacja „Ruch zastawiony dnia 30 września 1932 roku”. Strefa ta nigdy później nie została włączona do obszaru głębokiej eksploatacji innej kopalni i może służyć jako modelowy przykład wpływu płytkiej eksploatacji górniczej na powierzchnię terenu. Obecnie jej rejon jest klasyfikowany jako złoże niezagospodarowane Brzezinka (Jureczka 2005). 
(a) NMT 1883

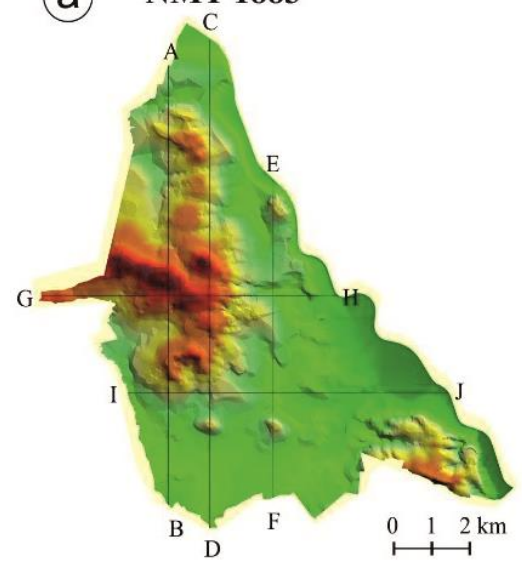

(C)

(7)

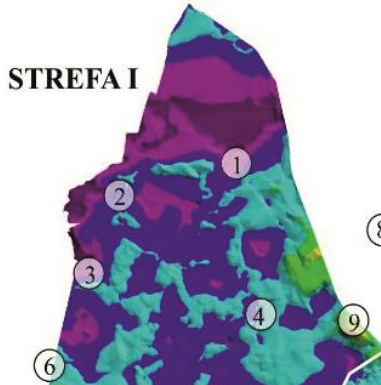

[m n.p.m.]

-330
-320

$-310$

$-300$

$-290$

$-280$

270

260

250

240

NMT 1993 - NMT 1883 (b) NMT 1993

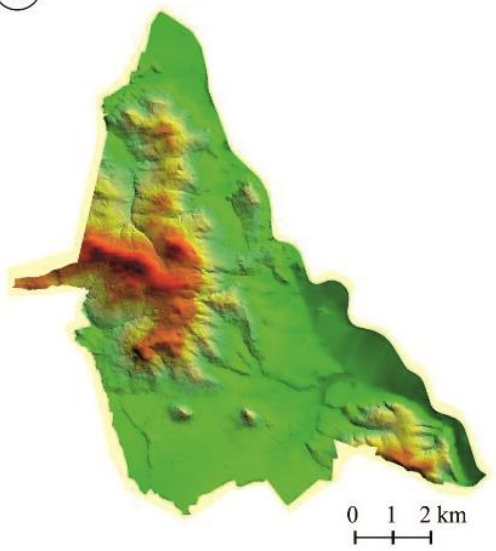

(8)

STREFA II

[m]

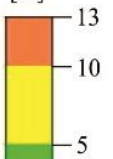

(10)
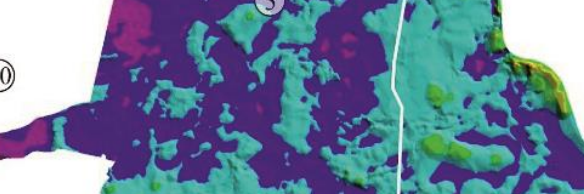

(11)

(11)

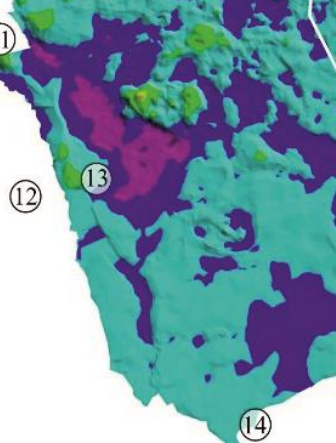

(14)

(15)

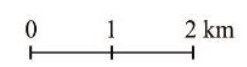


3. Strefa III o powierzchni $7,1 \mathrm{~km}^{2}$ (11\% powierzchni miasta), obejmująca południowo-wschodnią część Mysłowic. W strefie III nigdy nie prowadzono eksploatacji podziemnej. Rejon strefy III jest klasyfikowany jako złoże niezagospodarowane Dziećkowice (Jureczka 2005).

Strefa I zajmuje zachodnią i środkową część Mysłowic. W jej zasięgu znajduje się również większa część „miejsc podkopanych”, wydzielonych na mapach topograficznych z 1933 roku. Wyznaczone wówczas obszary obniżeń powstały przede wszystkim wskutek płytkiej eksploatacji węgla w obrębie kopalń: Mysłowice, Giesche, Karol oraz Książę, których rejony eksploatacji stanowiły sumę wielu wcześniej istniejących i eksploatowanych pól górniczych. Dwa inne obniżenia wydzielone na mapach z 1933 roku powstały prawdopodobnie wskutek eksploatacji i przetwarzania rud darniowych przez nieczynne już w tym czasie huty: Rozalia i Aleksandra (ryc. 2).

W wyniku analizy topografii obszaru badań, na podstawie otrzymanego zgeneralizowanego obrazu zmian wysokości względnych (ryc. 4c) można stwierdzić, że tereny o deniwelacjach od 0 do $-5 \mathrm{~m}$ i od -5 do $-10 \mathrm{~m}$ zajmują w równych częściach zdecydowaną większość powierzchni terenu. W strefie I koncentruje się występowanie deniwelacji poniżej $-15 \mathrm{~m}$. Ich położenie zawsze jest związane z bezpośrednim sąsiedztwem kopalń Mysłowice, Wieczorek, Staszic Wesoła oraz Ziemowit lub ich szybów wydobywczych (ryc. 4). Jest to spowodowane faktem, że kopalnie początkowo eksploatowały płytkie pokłady węgla, schodząc stopniowo coraz głębiej i rozszerzając zasięg eksploatacji w miarę rozwoju technologii wydobywczych (wentylacja, usuwanie wody, transport urobku do szybu i na powierzchnię). Na przykład w roku tworzenia wykorzystanej mapy archiwalnej (1883) kopalnia Mysłowice wydobywała węgiel na poziomie $135 \mathrm{~m}$ przekopami o długości 600 m (Jaros, Sulik 1990). Wartości te - głębokość i zasięg eksploatacji

$\leftarrow$ Ryc. 4. Wyniki analiz rzeźby terenu Mysłowic w postaci cyfrowych modeli:

a) Numeryczny Model Terenu, obraz rzeźby w 1883 roku; A-B, C-D, E-F, G-H, I-J - linie profili morfologicznych przedstawionych na ryc. 5; b) Numeryczny Model Terenu, obraz rzeźby w 1993 roku; c) Różnica wysokości powierzchni terenu jaka powstała w okresie 1983-1993; obraz wygenerowany przez superpozycję NMT 1983 i 1993;

Strefa I - obszar nieprzerwanej eksploatacji górniczej od połowy XVIII wieku do 1993 roku; Strefa II - obszar płytko powierzchniowej eksploatacji górniczej od połowy XVIII wieku do 1930 roku; Strefa III - obszar wyłączony z eksploatacji podziemnej. Numerami oznaczono lokalizację kopalń i szybów eksploatujących węgiel z obszaru Mysłowic w 1993 roku: 1 - KWK Mysłowice, 2 - Szyb Bończyk KWK Mysłowice, 3 - szyb Zachodni KWK Mysłowice, 4 - Szyb Wschodni KWK Mysłowice, 5 - Szyb Południowy KWK Mysłowice, 6 - Szyb Wschodni KWK Wieczorek, 7 - Szyb Roździeński KWK Wieczorek, 8 - KWK Niwka-Modrzejów, 9 - Szyb Kazimierz III KWK Niwka-Modrzejów, 10 - Szyb III KWK Staszic, 11 - Szyb Wacław KWK Wesoła, 12 - KWK Wesoła, 13 - Szyb Jan Henryk KWK Wesoła, 14 - Szyb Piast III KWK Ziemowit, 15 - Szyb Hołdunów KWK Ziemowit

Źródło: opracowanie własne 
- stale wzrastały w miarę rozwoju nowych technologii. W strefie I osiadania o wartościach rzędu $-6 \mathrm{~m}$ występują na polu górniczym kopalni Ziemowit, która zaczęła eksploatację w 1944 roku, w znacznej odległości od obecnych granic miasta. W północnej części strefy I znajduje się obszar poeksploatacyjny piasków podsadzkowych (obecnie teren zalewu Hubertus).

Strefa II jest położona we wschodniej części Mysłowic. Deniwelacje jakie powstały na tym obszarze są wynikiem wyłącznie płytkiej eksploatacji węgla, głównie przez kopalnię Nowa Przemsza w latach 1856-1932. Od tego czasu eksploatacja w strefie II nie została wznowiona. Deniwelacje tej strefy wynoszą do $-13 \mathrm{~m}$. Obszar tej strefy może służyć jako modelowy przykład wpływu wieloletniej płytkiej eksploatacji węgla kamiennego na powierzchnię terenu. Akta Archiwum Państwowego w Katowicach zawierają komplet dokumentów dotyczących szkód górniczych spowodowanych działalnością kopalni Nowa Przemsza. Były to odszkodowania za pęknięcia budynków i ogrodzeń oraz tworzenie zapadlisk i podmokłości na obszarach uprawnych.

Strefa III, leżąca w południowo-wschodniej części Mysłowic, jest jedynym obszarem miasta pozostającym poza wpływem eksploatacji węgla kamiennego. $\mathrm{W}$ tym rejonie przeważają deniwelacje rzędu $-5 \mathrm{~m}$. Pojawiają się również deniwelacje rzędu $-10 \mathrm{~m}$, leżące przy granicy ze strefą I w zachodniej części i wzdłuż granicy ze strefą II od północy. Deniwelacje te pojawiły się prawdopodobnie $\mathrm{w}$ następstwie naruszenia stabilności górotworu wskutek eksploatacji prowadzonej w rejonach I i II. W rejonie III pojawiają się wartości największych deniwelacji $-22 \mathrm{~m}$. W przeciwieństwie do stref I i II są one wynikiem wieloletniej eksploatacji powierzchniowej prowadzonej w lokalnym kamieniołomie, czynnym jeszcze na początku lat 50. XX wieku. Materiał z kamieniołomu (wapienie i dolomity) był wykorzystywany przez mieszkańców południowych dzielnic miasta. Do dziś w Dziećkowicach zachowały się budynki na podmurówce z kamieniołomu dziećkowickiego, małe budynki gospodarcze oraz niewielkie murki i ogrodzenia $\mathrm{z}$ tego materiału. Eksploatacja wapienia odbywała się poprzez stopniowe wybieranie materiału ze stoków, w wyniku czego powstały wąskie, głębokie rynny wyrobiskowe oraz rozległe, szerokie, nieckowate zagłębienia na stokach wzgórza. $\mathrm{W}$ jednej z rynien poeksploatacyjnych pojawiła się największa mysłowicka deniwelacja $-22 \mathrm{~m}$. Wapień z dziećkowickiego kamieniołomu służył także jako surowiec dla dwóch wapienników. Jeden z nich jest dość dobrze zachowany do chwili obecnej i leży w bezpośrednim sąsiedztwie deniwelacji $-22 \mathrm{~m}$. Kamieniołom ten jest jednym z nielicznych w Mysłowicach przykładów osiadania wskutek eksploatacji powierzchniowej. Również w Dziećkowicach znajduje się najrozleglejsze w Mysłowicach miejsce eksploatacji powierzchniowej, gdzie wydobywano piaski podsadzkowe, obecnie przekształcone w osadnik elektrociepłowni Jaworzno III. 

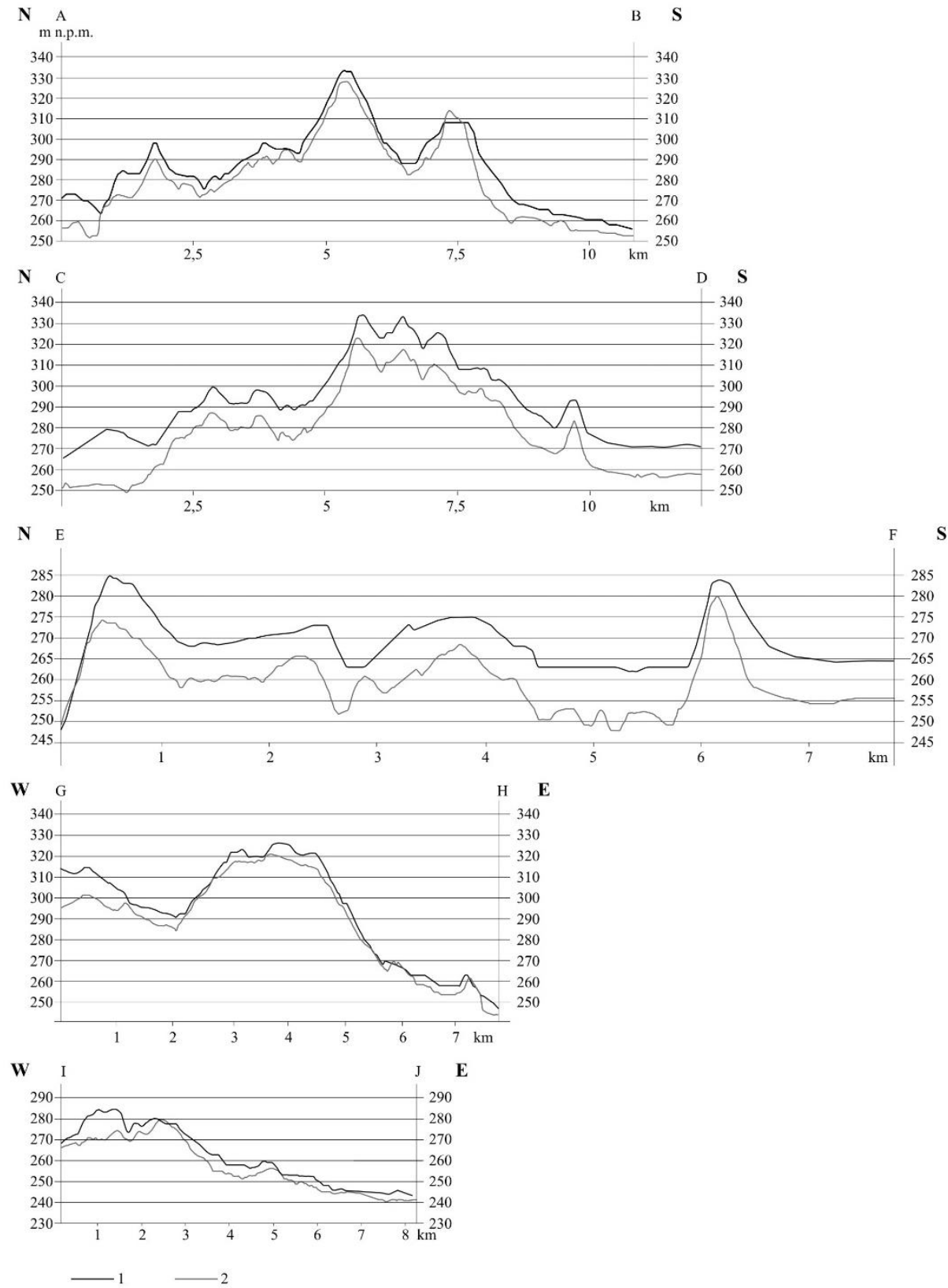

Ryc. 5. Profile hipsometryczne wzdłuż linii zaznaczonych na NMT 1883 (ryc. 4) Objaśnienia: 1 - profil morfologiczny wg NMT 1883, 2 - profil morfologiczny wg NMT 1993

Źródło: opracowanie własne 


\section{Podsumowanie}

$\mathrm{Na}$ podstawie analizowanych materiałów kartograficznych opracowanych za pomocą oprogramowania GIS (Global Mapper, MapInfo) wykazano wystąpienie deniwelacji w zakresie od -22 do 13 m, jakie powstały w latach 1883-1993 na obszarze Mysłowic. Pomimo że cała powierzchnia miasta uległa deniwelacjom różnego stopnia, główne elementy rzeźby terenu nie wykazują zasadniczych zmian. W. Długoborski (1977) podaje maksymalne i minimalne wartości wysokości powierzchni terenu Mysłowic od 336 do 238 m n.p.m., nie powołuje się jednak na wykorzystane źródłowe materiały kartograficzne. Pochodzą one zapewne $\mathrm{z}$ lat 60 . lub 70. XX wieku, a więc przedstawiają wartości uzyskane z ówczesnych map topograficznych. Można więc stwierdzić, że szacunkowa metoda dodania $3 \mathrm{~m}$ do wartości wysokości zwektoryzowanych poziomic $\mathrm{z}$ roku 1883 okazała się słuszna, gdyż materiały kartograficzne, z jakich korzystał W. Długoborski, musiały przedstawiać rzeźbę terenu obniżoną w stosunku do roku 1883 (338 do 240 m n.p.m.).

Nie jest możliwe uzyskanie pierwotnego obrazu morfologicznego Mysłowic, gdyż w roku wydania pierwszej mapy wielkoskalowej z rysunkiem poziomicowym (1883), wykorzystanej na potrzeby opracowania, eksploatacja węgla trwała już od ponad 100 lat.

Zastosowane metody oraz oprogramowanie GIS umożliwiają także przedstawienie wszelkich deformacji oraz zmian terenu powstałych w wyniku innych działań antropogenicznych (zmiany infrastruktury powierzchniowej) lub naturalnych (zmiany sieci rzecznych, zasięgu lasów itp.), co zostało częściowo wykorzystane w pracy.

Niniejsze opracowanie jest wstępem do dalszych badań, które w założeniu mają ukazać dynamikę zmian rzeźby terenu miasta za pomocą tworzenia i porównywania szeregu modeli numerycznych terenu dla obszaru Mysłowic. Kolejne modele w założeniu mają obrazować cztery główne okresy powojennego kopalnictwa, które wydzielił w swoim opracowaniu W. Konopko (2010):

1. 1945-1947 - powojenna odbudowa zdolności produkcyjnych kopalń oraz kompletowanie załóg górniczych;

2. 1948-1979 - intensywny rozwój wydobycia w rezultacie rozbudowy mocy produkcyjnych kopaln istniejących, rozwój środków technicznych wydobycia;

3. 1980-1988 - stabilizacja (z wyjątkiem 1981 roku) wydobycia na wysokim poziomie;

4. Od roku 1989 - systematyczny spadek wielkości wydobycia, likwidacja kopalń ze względu na wyczerpywanie zasobów, a nawet likwidacja kopalń ze znacznymi zasobami, uznanych za „trwale nierentowne”, ograniczenie inwestowania.

Obniżenia terenu powstały wokół kopalń w wyniku prowadzenia w tych rejonach wczesnej płytkiej eksploatacji, a następnie jej intensyfikacji na głębszych 
poziomach. Zastosowanie metod GIS umożliwia śledzenie zmian powierzchni terenu pod wpływem eksploatacji powierzchniowej lub podziemnej za pomocą użycia wyłącznie takich materiałów, jakimi są mapy topograficzne. Przed pojawieniem się narzędzia analitycznego, jakim jest GIS, osiadania można było określić wyłącznie na podstawie specjalistycznych obliczeń dotyczących eksploatacji prowadzonych przez kopalnie. Obecnie wszelkiego typu zmiany można monitorować na bieżąco dzięki geodezji i z zastosowaniem metod pomiarów satelitarnych. Jeszcze w roku 1990 twierdzono, że nie można odtworzyć skutków robót górniczych od ich początku. Jest to twierdzenie aktualne, jednak można przesunąć granicę określania tychże skutków (choć z pewnym marginesem błędu) na rok 1883.

Według J. Chwastka i in. (1990) w ciągu lat 80. XX wieku rejon kopalni Wesoła uległ obniżeniu o 2-3 m, przy prognozowanych następnych dużych deformacjach rzędu 5-10 m, mających nastąpić wskutek intensyfikacji wydobycia. Autorzy niniejszej pracy otrzymali dla tego rejonu wartość osiadania rzędu $-16 \mathrm{~m}$, potwierdzając tym samym słuszność obranej metody. Pomimo opisanego błędu związanego z precyzją pomiarową XIX wieku, wielkości osiadań zostały ocenione jako wiarygodne. Otrzymane wyniki zweryfikowano w terenie poprzez obserwację i rozmowy z mieszkańcami dzielnicy Mysłowice-Wesoła oraz poprzez obserwację pozostałych obszarów o największym stopniu osiadania. Bardzo skuteczną metodą weryfikacji błędów otrzymanych wyników są obserwacje terenowe oraz, jak to ma miejsce w przypadku współautorki opracowania, wieloletnia znajomość rodzinnego miasta i problemów górnictwa $\mathrm{z}$ racji wychowania w rodzinie górniczej.

W Mysłowicach bardzo wcześnie zaczęto niwelować skutki osiadań poeksploatacyjnych poprzez stosowanie podsadzki. Kopalnia Mysłowice jako pierwsza kopalnia w Europie od 1902 roku stosowała na skalę przemysłową podsadzkę do likwidacji pustek poeksploatacyjnych (Jaros, Sulik 1990). Historyczna zabudowa Mysłowic pochodząca z końca XIX wieku oraz przełomu XIX i XX wieku, leżąca w rejonie największych osiadań, nie uległa widocznym bądź drastycznym zniszczeniom (Sulik 2007). Można stwierdzić, że w rejonie Mysłowic skutki osiadań nie są tak katastrofalne, jakby można było oceniać po rzędzie uzyskanego przedziału zmian wysokości względnych osiągających $-20 \mathrm{~m}$. W centrum Mysłowic występowały deformacje nieciągłe o charakterze powierzchniowym (zapadliska), będące skutkiem wczesnej eksploatacji górniczej, prowadzonej płytkimi wyrobiskami korytarzowymi z prowadzoną wówczas prawdopodobnie likwidacją pustek metodą na zawał lub pozostawianiem korytarzy $\mathrm{z}$ drewnianą obudową, która z czasem butwiała. Zapadliska jakie powstawały w wyniku takich działań, ujawniające się w różnym czasie po zakończeniu eksploatacji, były na bieżąco likwidowane przez zasypywanie lub w przypadku ich odnowienia przez zatłaczanie do pustek pyłów poelektrownianych, co okazało się skuteczną metodą (Strzałkowski 2000). 
Bardziej dotkliwe i widoczne okazały się skutki wczesnej eksploatacji górniczej prowadzonej w rejonie młodszej niż KWK Mysłowice kopalni Wesoła. Stare domy położone $\mathrm{w}$ pobliżu kopalni są $\mathrm{w}$ wielu przypadkach $\mathrm{w}$ widoczny sposób odchylone od pionu, ankrowane, a część z nich została wyburzona ze względu na stopień zniszczenia.

Wszelkie wątpliwości pojawiające się w trakcie tworzenia opracowania były wyjaśniane dzięki życzliwości pracowników Urzędu Miasta oraz Katowickiego Holdingu Węglowego.

\section{Podziękowanie}

Autorzy opracowania dziękują recenzentom za uwagi, które pomogły wzbogacić treść artykułu. Dziękujemy również dr Dariuszowi Dukaczewskiemu z Instytutu Geodezji i Kartografii w Warszawie za wyjaśnienie kwestii precyzji pomiarowych w XIX wieku.

\section{LITERATURA}

Centralna Baza Danych Geologicznych Państwowego Instytutu Geologicznego, http://dm. pgi.gov.pl/.

Chwastek J., Janusz W., Maciaszek J., Mikołajczak J., Repelowski A., Szewczyk J., 1990, Deformacje powierzchni terenu spowodowane działalnościq górnicza, „Zeszyty Naukowe Akademii Górniczo-Hutniczej, Sozologia i Sozotechnika", 30, Gliwice.

Długoborski W. (red), 1977, Mystowice. Zarys rozwoju miasta, Wydawnictwo Śląsk, Katowice.

Dokumentacja kopalni Nowa Przemsza, 1932, Archiwum Wyższego Urzędu Górniczego, Katowice.

Dulias R., 2013, Denudacja antropogeniczna na obszarach górniczych na przykładzie Górnoślaskiego Zaglębia Węglowego, Uniwersytet Śląski, Katowice.

Jaros J., 1965, Historia górnictwa weglowego w zaglębiu górnoślaskim do 1914 roku, Wydawnictwo Polskiej Akademii Nauk, Wrocław-Warszawa-Kraków.

Jaros J., 1969, Historia górnictwa węglowego w zagłębiu górnośląskim w latach 19141945, Śląski Instytut Naukowy, Katowice.

Jaros J., 1972, Stownik historyczny kopalń wegla kamiennego na ziemiach polskich, „Zeszyty Naukowe", 59, Śląski Instytut Naukowy, Katowice.

Jaros J., Sulik A., 1990, Kopalnia „Mystowice”. Dwa wieki górnictwa, Śląski Instytut Naukowy, Katowice.

Jureczka J., 2005, Atlas geologiczno-złożowy polskiej i czeskiej części Górnoślaskiego Zaglębia Węglowego 1:200 000, Państwowy Instytut Geologiczny i Ministerstwo Środowiska, Warszawa.

Kondracki J., 2002, Geografia regionalna Polski, Wydawnictwo Naukowe PWN, Warszawa.

Konopko W., 2010, Wydobycie węgla i destrukcja górotworu w Górnośląskim Zagłębiu Węglowym, „Przegląd Górniczy”, 11(1056), t. 66.

Mazurek K., 2014, Wpływ eksploatacji węgla kamiennego na ukształtowanie powierzchni wybranych fragmentów miasta Ruda Ślaska, „Acta Geographica Silesiana”, 15, Sosnowiec. 
Strzałkowski P., 2000, Wpływ płytkiej eksploatacji górniczej na zagrożenie powierzchni terenu deformacjami nieciagtymi, „Zeszyty Naukowe Politechniki Śląskiej”, seria Górnictwo, 246, Gliwice.

Sulik A. (red.), 1997, 160 lat kopalni węla kamiennego „Mysłowice” 1837-1997, Redakcja Życia Mysłowic, Mysłowice.

Sulik A., 2007, Historia Mysłowic do 1922 roku, Urząd Miasta Mysłowice, Mysłowice.

Wojciechowski T., 2007, Osiadanie powierzchni terenu pod wptywem eksploatacji węgla kamiennego na przykładzie rejonu miasta Knurów, „Przegląd Geologiczny”, 55(7), Warszawa.

\title{
Wykaz map tematycznych
}

Mapy historyczne Górnego Śląska z zaboru pruskiego (arkusze Mysłowice i Imielin) w skali 1:50 000, wydane przez C. Brik, 1860, Berlin.

Mapy topograficzne Górnego Śląska z zaboru pruskiego (Messtischblatty) w skali 1:25 000, wydawnictwo Lith. Anst. v. Leopold Kraatz, 1883, Berlin.

Mapy górnicze Górnego Śląska z zaboru pruskiego (Floztkarte des Oberschlesischen Steinkohlenbeckens) w skali 1:10 000, wydawnictwo Lith. Anst. v. Leopold Kraatz, 1902, Berlin.

Mapy topograficzne Polski w skali 1:25 000, wydane przez Wojskowy Instytut Geograficzny, 1933, Warszawa.

Mapy topograficzne niemieckie Górnego Śląska w skali 1:25 000, wydane przez Wojskowy Instytut Geograficzny, 1942, Warszawa.

Mapy topograficzne Polski w skali 1:25 000, wydane przez Centralny Ośrodek Dokumenttacji Geodezyjnej i Kartograficznej, 1993, Warszawa.

\section{USE OF DIGITAL ELEVATION MODELS IN STUDIES OF CHANGES IN THE GEOGRAPHICAL ENVIRONMENT OF THE CITY MYSLOWICE}

\begin{abstract}
The aim of the study is to demonstrate the usefulness of methods of analysis in GIS software, in broad studies of changes in the geographical environment of the city Myslowice. Geographical environment are created of natural and anthropogenic elements, concluded on maps for centuries. Assumed research method showed a very high possibility of using GIS software to analyze the changes, which took place in the town of Myslowice in the years 1883-1993. For this purpose, two digital elevation model (DEM) were generated by vectorization of izohips and altitude point. The first model was based on the old German Messtischblatt topographic maps at scale of 1:25 000 from the years 1883-1942. The second model was generated from Polish topographic maps at a scale of 1:10 000 from the year 1993. All these maps have been calibrated (registered) to a common coordinate system Poland 1992. Generating uneven-aged DEM also gave the opportunity to track changes in morphology on selected lines of cross-sections. Myslowice is a city of the Upper Silesian Coal Basin, in which the exploitation activity is dating back more than two hundred years. However, due to the limited number of maps the study only shows the effects of 110 years of exploitation. The usefulness of the method was confirmed in determining the precise areas of the city, which were hardest hit by the effects of mining activities. This fact was also verified in the field. As a result of the surface exploitation in several large quarries traces of underground mining operations are erased,
\end{abstract}


but with a careful analysis they can be distinguished from each other. With GIS software and precise calibration of old maps is it possible to trace the changes in the components of the geographical environment, such as rivers, water reservoirs, roads, building development, afforestation. In addition, it enables the precise location of some elements of the environment that no longer exist such as old excavation of raw materials, sand, clay and limestone or traces of the former ironworks.

Key words: GIS, historical cartography, digital elevation model, mining deformation.

Mgr Małgorzata Manowska

Mgr Maciej Szuba (doktorant)

Katedra Geologii Podstawowej

Wydział Nauk o Ziemi

Uniwersytet Śląski 